\title{
Identification in Immuno-Electron Microscopy of Solitary Multi-Polar Peripheral Neurons of Adult Opisthorchis viverrini by Antibody Against Rat Diacylglycerol Kinase $\zeta$
}

\author{
Identificación por Microscopía Imuno-Electrónica de las Neuronas Periféricas Multipolares Solitarias \\ del Opisthorchis viverrini Adulto Mediante Anticuerpo contra la Diacilglicerol Kinasa de Ratas
}

\begin{abstract}
Wiphawi Hipkaeo,"**; Nawaporn Techataweewan"*; Waraporn Sakaew",**; Wanchai Maleewong"*** Banchob Sripa $^{* * * * *}$; Surang Chomphoo,**; Yasukazu Hozumi*****; Kaoru Goto***** \& Hisatake Kondo,***
\end{abstract}

HIPKAEO, W.; TECHATAWEEWAN, N.; SAKAEW, W.; MALEEWONG, W.; SRIPA, B.; CHOMPHOO, S.; HOZUMI, Y.; GOTO, K. \& KONDO, H. Identification in immuno-electron microscopy of solitary multi-polar peripheral neurons of adult Opisthorchis viverrini by antibody against rat diacylglycerol kinase. Int. J. Morphol., 34(2):471-477, 2016.

SUMMARY: By utilizing the antibody for rat DGK $\zeta$ a substantial number of immunopositive cells were found in the $O V$ (Opisthorchis viverrini). The immunopositive cells appeared solitarily and they were distributed rather symmetrically to the longitudinal axis of the $O V$. Some of them were located in close proximity to internal organs such as uterus, ovary, testes, vitelline glands and guts. The immunostained cells extended tapering processes horizontally or obliquely to the $O V$ longitudinal axis. In immuno-electron microscopy, the immunopositive cells were characterized by intensely immunostained mitochondria and weakly immunostained cytoplasm and immunonegative chromatin-poor nucleus. Vacuoles of various sizes without the immunoreactivity were also contained in the cells. Thin cellular processes without the immunoreactivity were found to enclose thinly the entire surfaces of the immunostained cells and processes, and they were in continuity with the interstitial partition-like processes which contained nuclei and aggregation of microfibrils at some distance from the cytoplasmic envelopes. The present finding suggests the possibility that the immunostained cells were peripheral neurons enveloped by peripheral glia and that the glia are of mesenchymal origin because of their cytoplasmic continuity to the interstitial partition-like processes. The motor or sensory nature of the neurons remains to be elucidated.

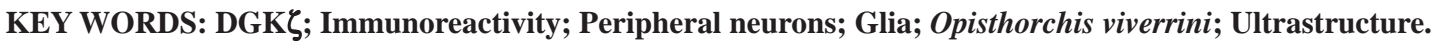

\section{INTRODUCTION}

The phylum platyhelminths, flatworms, are composed of Cestoda, Trematoda and Turbellaria, and they are the lowest animals that exhibit the cephalization and distinguishable central and peripheral nervous system. While the central nervous system in the majority of these animals consists of well-defined but varying numbers of nerve cords, nerve rings, and cerebral ganglia, the peripheral nervous system is made up of a complex network of thin nerve plexuses (Morris et al., 2007). Liver flukes, Opisthorchis viverrini $(\mathrm{OV})$, represent the trematode and it is a strong risk factor of cholangiocarcinoma in Thai and southeast Asian countries (Sriamporn et al., 2004; Shin et al., 2010). It is evident that the mechanisms to drive the parasite migration within human hosts along their bile duct into the biliary tree, the sites of patent attachment and infection, rely on a well-developed and coordinated role by peripheral sensory as well as neuromuscular motor nervous systems of the OV. Detailed morphological knowledge of the peripheral nervous systems of the parasite is thus important for understanding the mechanisms and behaviors of the $\mathrm{OV}$ in its hosts. Moreover, such knowledge may provide alternative drug targets for anthelminthics. The nervous system of the platyhelminths including the OV has been studied in immunofluorescence histochemistry at light microscopic levels with antibodies against several neurotransmitters and neuromodulators, whose functions are known to work largely in the motor nervous system (Gustafsson et al., 2001, 2002). However, there has so far, been neither ultrastructural

Nanomorphology-based Apply Research Group, Faculty of Medicine, Khon Kaen University, Khon Kaen 40002, Thailand.

** Electron Microscopy Unit, Department of Anatomy, Faculty of Medicine, Khon Kaen University, Khon Kaen, Thailand.

*** Parasitology, Faculty of Medicine \& Research and Diagnostic Center for Emerging Infectious Diseases, Khon Kaen University, Khon Kaen, Thailand.

***** Pathology, Faculty of Medicine, Khon Kaen University, Khon Kaen, Thailand.

***** Department of Anatomy, School of Medicine, Yamagata University, Yamagata, Japan. 
HIPKAEO, W.; TECHATAWEEWAN, N.; SAKAEW, W.; MALEEWONG, W.; SRIPA, B.; CHOMPHOO, S.; HOZUMI, Y.; GOTO, K. \& KONDO, H. Identification in immuno-electron microscopy of solitary multi-polar peripheral neurons of adult Opisthorchis viverrini by antibody against rat diacylglycerol kinase $\zeta$. Int. J. Morphol., 34(2):471-477, 2016.

knowledge of moter neurons of these parasites nor light and electron microscopic information of their peripheral sensory neurons (Leksomboon et al., 2012a).

On the other hand, there has been well-known data showing that the phosphoinositides (PIs) of the plasma membrane play important roles in the signal transduction in mammals including the nervous system (Putney et al., 1983; Goto et al., 2008). In the PI-signal, diacylglycerol (DAG) is the first identified mammalian second messenger to enhance the activity of protein kinase $\mathrm{C}$ (PKC) and it is converted to phosphatidate, another messenger, by DAG kinase (DGK). Therefore, DGK is a key regulator of PKC activity by attenuation of DAG and it is an important regulator of phosphatidate (Kanoh et al., 2002; Goto et al.). Based on the information described above as well as previous findings on the identification of several molecules involved in the PI-signal in C. elegans representing Nematoda which is phylogenically the next higher phyrum to the $O V$ representing Trematoda (Merida et al., 2008; Tsunozaki et al., 2008), the present authors recently examined the occurrence of DGK-like immunoreactivities in the $O V$ using antibodies against various DGK isoforms of rats, and have reported in immuno-light and electron microscopy the occurrence of cells immuno-stained with the DGK $\gamma$ antibody selectively in the Mehlis gland of the $O V$, although the exact identification of the DGK-like molecule remains to be elucidated.

With this viewpoint in mind, as the second of a series of studies on the localization of DGK-like immunoreactivity in the $O V$, the present study reported outside the $O V$ central nerves including the cephalic ganglia, the appearance of a certain number of multi-polar large cells which were solitarily immunostained with the rat DGK $\zeta$ antibody. Their ultrastructural characteristics including the association of immunonegative cytoplasmic processes thinly enveloping the immunopositive cells lead to the possibility that the immunopositive cells were peripheral neurons and that the cytoplasmic envelopes were the peripheral glia.

\section{MATERIAL AND METHOD}

Metacercariae of $O V$ s were collected from naturally infected cyprinid fish and were used to infect the golden Syrian hamsters by stomach intubation. Adult flukes were collected after 4 weeks infection. OVs were then fixed with $4 \%$ paraformaldehyde/ $0.1 \mathrm{M}$ phosphate buffer for $2 \mathrm{~h}$. Specimens were dipped in $30 \%$ sucrose/0.1 M phosphate buffer and then cryostat sections of $20 \mathrm{~m}$ thickness were made. The sections were then permeabilized with $0.1 \%$ TritonX-100/
PBS, incubated with $0.3 \% \mathrm{H}_{2} \mathrm{O}_{2} /$ methanol, then $5 \%$ normal goat serum/PBS for $30 \mathrm{~min}$. The sections were incubated with rat-DGK $\zeta$ rabbit $\operatorname{IgG}(1 \mu \mathrm{g} / \mathrm{mL})$ for $48 \mathrm{~h}$. The specificity of the antibody was confirmed and reported previously. The sections were subsequently incubated with biotinylated antirabbit IgG secondary antibody (Vector Laboratories, Burlingame, CA USA) diluted at 1:200 for diaminobenzidine (DAB) reaction by VECTASTAIN Elite ABC kit (Vector Laboratories, Burlingame, CA USA). After DAB-reaction, some of the sections were fixed with $2.5 \%$ glutaraldehyde in $0.1 \mathrm{M}$ phosphate buffer for $1 \mathrm{~h}$ and further with $1 \% \mathrm{O}_{\mathrm{s}} \mathrm{O}_{4}$ in phosphate buffer for $1 \mathrm{~h}$. After en-bloc staining with urany acetate solution, the sections were embedded in Epon at 60 ${ }^{\circ} \mathrm{C}$ for 1 day. Ultrathin sections without lead staining were observed using Jeol 1010 electron microscope.

In control experiments, the primary antibody alone was omitted in the process of treating sections for immunohistochemistry.

All subsequent procedures were conducted in accordance with Guidelines for the Care and Use of Laboratory Animals at Khon Kaen University. The study was reviewed and approved by the ethics board with the ethics number 0514.1.12.2/70.

\section{RESULTS}

Immuno-light microscopy. Solitary cells with multiple processes were found to be intensely immunopositive with the antibody against rat DGK $\zeta$ throughout the parenchyma of $O V$, although almost all tegument cells coverivg the surface of $O V$ were weakly and diffusely immunostained (Figs. 1-2). The immunopositive cell somata were 10-20 $\mu \mathrm{m}$ and the processes were radiated from the somata at the extension of $30-90 \mu \mathrm{m}$ in single sections. While the immunopositive cells were sparse in the cephalic portion of the $O V$, most of them were distributed from sites closely cephalic to the ventral sucker till those close to the end of the caecum.

In almost all of roughly consecutive coronal sections of the entire body of the $O V$ except for its marginal portions, a substantial number of the immunopositive cells appeared constantly and they were arranged symmetrically with regard to the median longitudinal axis in the coronal plane of the OV (Fig. 1).

Although the immunoreactivity appeared more or less positive throughout the cells and cell processes, their perikaryal somata and proximal processes were especially intensely immunostained where the immunoreactivity 


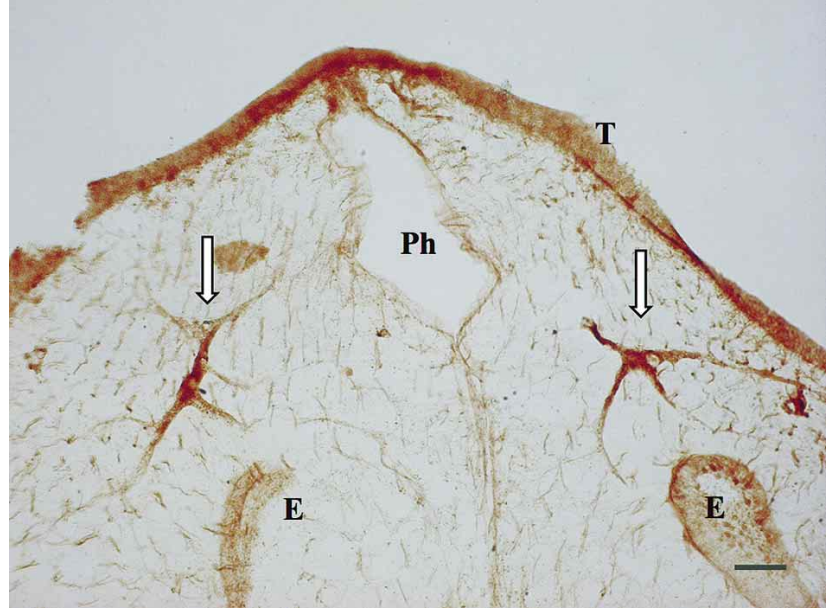

Fig. 1. Immunolight micrograph of $O V$ in coronal section, showing multipolar neurons (arrows) bilaterally in a symmetrical pattern in close to the pharynx $(\mathrm{Ph})$ and caecum $(\mathrm{C})$. A tapering process approaches to the base of tegument $(\mathrm{T})$. Bar represents $50 \mu \mathrm{m}$.

appeared in forms of numerous small granules. The processes were extended horizontally or obliquely to the longitudinal axis of the $O V$, but scarcely extended in a longitudinal direction. Some of the processes were extended to the internal organs such as guts, testes, vitelline glands, ovary, and uterus (Fig. 2a), while other processes were tapered and extended within the teguments (Fig. 2b). None of the processes from two adjacent immunopositive cells were found to approach and contact each other mutually.

Immuno-electron microscopy. In the immunopositive cells, the immunoreactive materials were more or less deposited diffusely in the cytoplasmic matrix. In contrast, the mitochondria having typical cristae were most intensely immunoreactive, although most of them were centrally raptured probably due to the DAB reaction (Figs. 3a-b). The poor chromatin nucleus was immunonegative. Lysosomes were few and numerous vacuolar/vesicular profiles were contained in the cells and their interiors were immunonegative.

The immunopositive process taperings within the teguments were practically impossible to differentiate from the tegument cells in immuno-DAB electron microscopy, because the latter exhibited, though weaker, immunostaining, and it was thus unsuccessful to trace the trajectory of the former.

Thin and immunonegative processes, 200 700 nm thick, were found to envelope the entire surfaces of the immunopositive cells and their processes (Figs. 4a-b). The cytoplasm of the immunonegative cell processes appeared finely filamentous, although difficult to define clearly

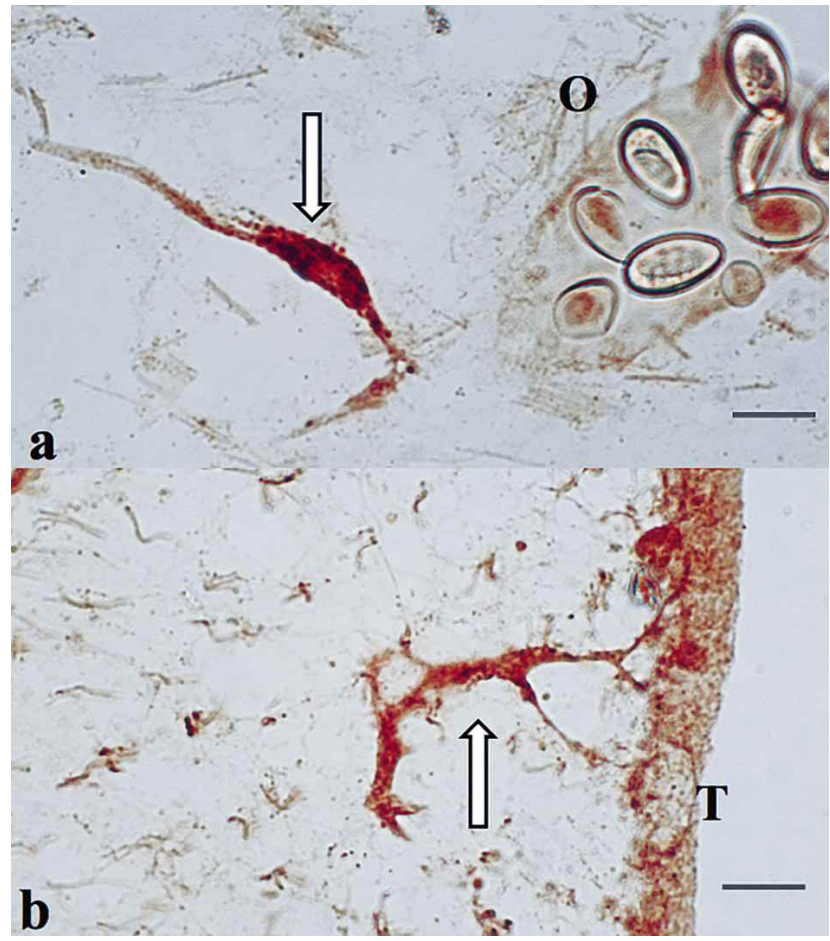

Fig. 2. Immunolight micrographs of $O V$ in coronal sections showing multipolar neurons in close proximity to the uterus (U) [a] and the tegument $(\mathrm{T})[\mathrm{b}]$. Note neuronal process extending within the tegument. Bars represent $20 \mathrm{~mm}$ [a and b].

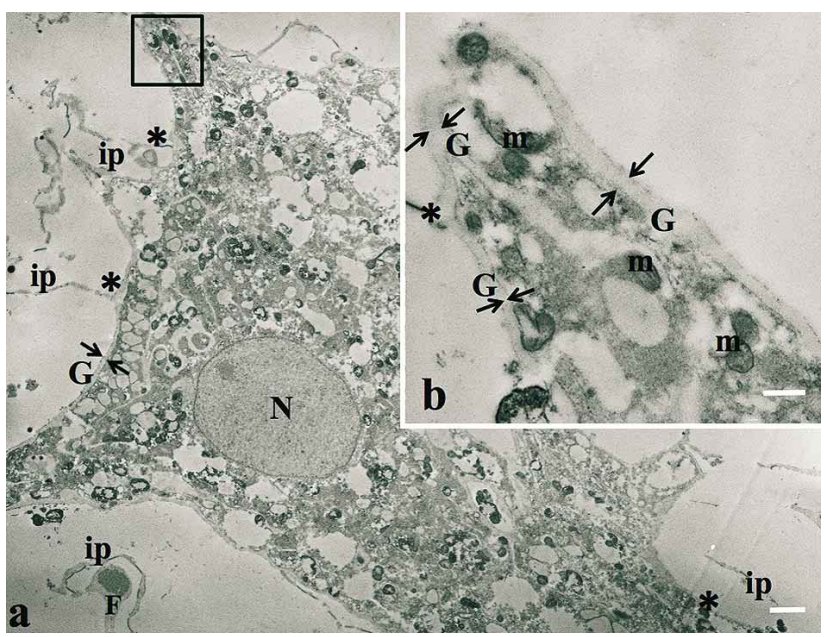

Fig. 3. Immuno-electron micrographs of multipolar neuron corresponding to the neuron shown in Fig 1. The immunopositive neuron is held in place by interstitial partition processes (ip) [a]. Higher magnification micrograph [b] of a portion of multiple neuron corresponding to the area enclosed by rectangle in [a]. Note mitochondria with cristae $(\mathrm{m})$ exhibiting intense immunoreactivity. Also note the enclosure of neuronal surface by thin immunonegative processes of glial nature with filamentous appearance (G, sandwiched zone by two facing arrows). Asterisks indicate confluent points between glial envelopes and interstitial partitionlike processes (ip). $\mathrm{F}=$ aggregations of microfibrils in partitionlike processes. $v=$ vacuoles. Bars represent $2 \mu \mathrm{m}$ [a], $500 \mathrm{~nm}$ [b]. 


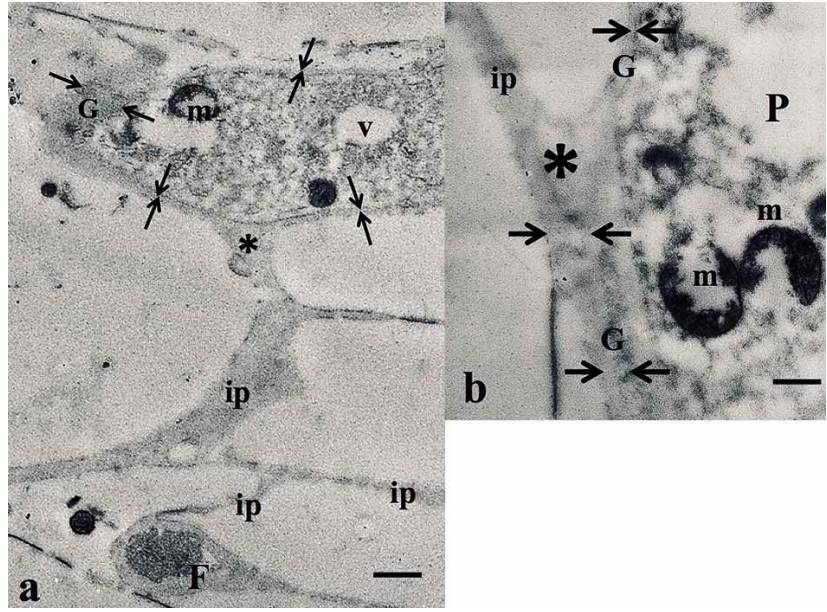

Fig. 4. Immuno-electron micrographs of distal [a] and proximal [b] neuronal process $(\mathrm{P})$ containing intensely immunopositive mitochondria $(\mathrm{m})$. Note immunonegative process of glial nature (G, sandwiched zone by two apposing arrows) in continuity $(*)$ with interstitial partition-like processes (ip). v:vacuoles. Bars represent $1 \mu \mathrm{m}$ [a], $500 \mathrm{~nm}$ [b].

because of their low electron density due to the treatment with triton- $X$ in immuno-DAB electron microscopy. No cellular junctional substructures were found at sites of apposition between the immunopositive cells and the immunonegative cellular envelopes. The immunonegative cytoplasmic envelopes were continuous to thin processes, 200-300 nm thick, which extended randomly and widely throughout the interstitium of the $O V$ parenchymes, resulting in an appearance of partitions of the interiors. Nuclei containing heterochromatins and aggregations of microfibrils, $10 \mathrm{~nm}$ in thickness, were contained in portions of the partition-like processes mostly at some distance from the cytoplasmic envelopes apposed to the immunopositve cells (Fig. 5).

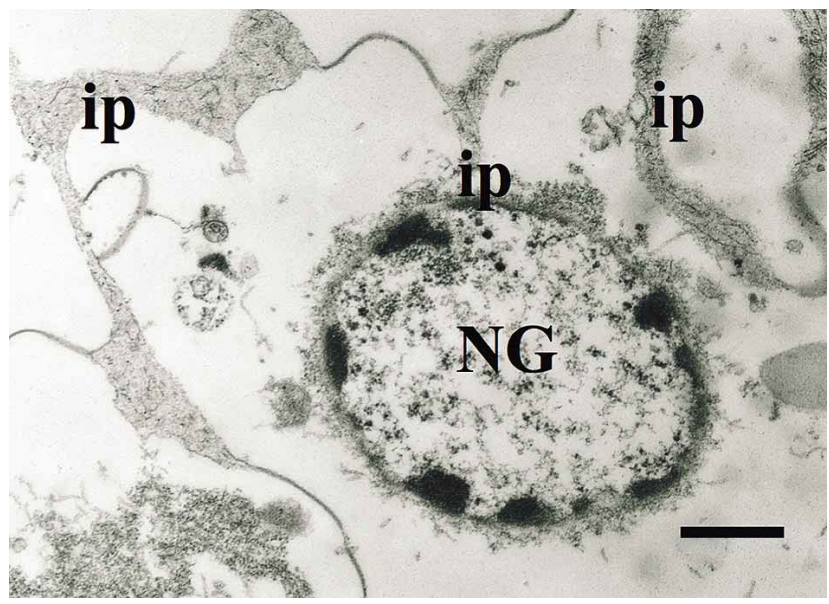

Fig. 5. Ultrastructural profile of nucleus (NG) in a partition-like process in continuity with, but at some distance from, the glia thinly enveloping the immunopositive neuron. Bar represents $1 \mu \mathrm{m}$

\section{DISCUSSION}

Assuming that the general understanding of vertebrate histology is applied to the parasite histology, the feature of such long multipolar cells seen in the present $O V$ with DGK $\zeta$ like immunoreactivity leads us to think two possibilities on the identification of the immunopositive cells in the OV: neurons and macrophages (Fawcett et al., 1994). The latter cells in the vertebrates are characterized by the presence of numerous lysosomes. Because the present immunopositive cells were found to be poor in the lysosomes in immuno-electron microscopy, the identification of the immunopositive cells as macrophages is much less likely, and it is thus more probable that the immunopositive cells are neurons in the peripheral nervous system of the $O V$. In addition to the cell shape and interior, vertebrate neurons are characterized by a feature to be enveloped by cells of glial nature (Fawcett et al.). In this regard, it should be noted that thin immunonegative cytoplasmic envelopes were disclosed to be apposed to the immunopositive cell surfaces in a highly similar way to the vertebrate glial cells. This feature further supports the possible identification of the immunopositive cells as peripheral neurons and that of the immunonegative cytoplasmic envelopes as glia of the $O \mathrm{~V}$.

However, there have been debates on the ultrastructural criteria of glial cells in the nervous system of the platyhelminths, flatworms (Radojcic \& Pentreath, 1979; Biserova, 2008), although the functional significance of glial cells in a way similar to that in verterbrates has been well stated in the nematode, next higher phylum to the platyhelminths, represented by $C$. elegans (Oikonomou \& Shaham, 2011). This debate is mainly due to the fact that sufficient ultrastructural information has so far been lacking about the nervous system of the platyhelminths, especially of OV (Leksomboon et al., 2012a), in spite that there have been ample numbers of immuno-fluorescence microscopic studies of the peripheral and central nervous systems in the platyhelminths in which numerous neuron somata are clearly demonstrated in the immuno-light microscopy (Barton $e t$ al., 1993; Gustafsson et al., 2001, 2002; Leksomboon et al., 2012b). The lack thereof, seems to be understandable because it is technically impossible to examine at the electron microscopic level the immuno-labeled neurons. Needless to say, it is also almost impossible to identify without any histological markers for further ultrastructural analysis individual peripheral, but not central, neurons, which must be distributed rather loosely among non-neural mesenchymal tissue cells, in light microscopy using conventional epon sections of the $O V$ and other platyhelminths. In constrast to the immunofluorescence light microscopy and conventional electron microscopy, the utilization of diaminobenzidine 
HIPKAEO, W.; TECHATAWEEWAN, N.; SAKAEW, W.; MALEEWONG, W.; SRIPA, B.; CHOMPHOO, S.; HOZUMI, Y.; GOTO, K. \& KONDO, H. Identification in immuno-electron microscopy of solitary multi-polar peripheral neurons of adult Opisthorchis viverrini by antibody against rat diacylglycerol kinase. Int. J. Morphol., 34(2):471-477, 2016.

(DAB) as the immuno-histological marker is advantageous in identification of any target cells in both immuno-light and electron microscopy, as having been clearly demonstrated in many immunohistochemical studies of mammalian specimens as well as in our previous and present studies (Kondo, 1985; Stirling, 1990; Kondo \& Hipkaeo, 2013). By the technical advantage, the present immunoelectron microscopy clearly disclosed that the immunostained cells were not directly exposed to the interstitial spaces, but their surfaces were enveloped by immunonegative thin processes.

In addition to the interrelation between the immunopositive cells and the immunonegative cytoplasmic envelopes, the latter were found to be continuous to the interstitial partition-like processes which contained the nuclei rich in chromatin along the thin trajectory at some distance from the enveloping sites. The partition-like processes may be analogous to the interstitial fibroblasts in vertebrates. This feature suggests that the peripheral glial cells in this parasite species are, at least partially, of mesenchymal origin as suggested by the previous authors in light microscopy (Bullock \& Horridge, 1965). This type of glia is thus similar to the type 3 glia in the main codes of a Cestoda by Biserova.

The ultrastructural interrelation of the presumptive sensory neurons with the immunonegative glial envelopes of the neurons in continuity to the partition-like processes containing nuclei and aggregations of microfibrils are schematically line-drawn (Fig. 6).

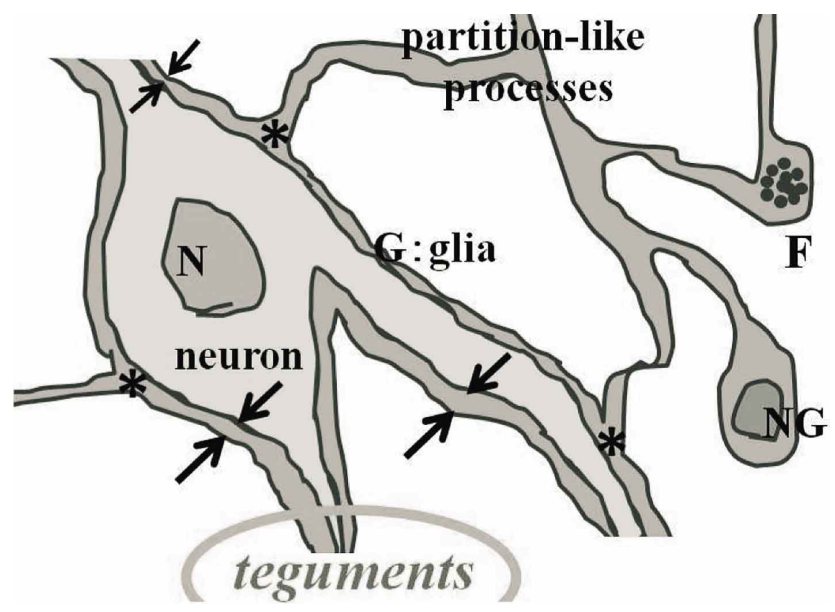

Fig. 6. Schematic drawing of ultrastructural interrelation of the immunopositive multipolar neuron of presumptive sensory nature with glial envelopes which are continuous with interstitial partitionlike processes containing microfibril-aggregates and nuclei along their trajectory. Abbreviations are used in the same way as in Figs. 3 and 4.
With regard to the sensory or motor nature of the immunopositive neurons, several questions remain to be clarified: what kind of cells do the immunopositive neurons form synaptic contact with? Although previous studies have already shown neuronal profiles containing various types of vesicles in neuropiles of the central ganglia in the platyhelminths (Sukhdeo \& Sukhdeo, 1990; Terenina et al., 2009; Leksonboom et al., 2012b), the present study failed to disclose any such neuronal profiles abutting on the immunopositive neurons and their proximal processes, or to disclose such aggregations of vesicles at submembranous sites of the immunopositive neuronal proximal processes on which another neuronal process abuts. The occurrence of the immunopositive tapering processes extending into the tegument is in favor of the possibility of the sensory nature of the immunopositive neurons. However, because of embedment of the tapering processes in similarly DAB-reaction-caused brown-colored tegument cell aggregations in immuno-light microscopy, it was almost impossible to differentiate the tapering processes selectively in immuno-electron microscopy. Because of a similar reason, it was practically difficult to trace distal processes of the immunopositive neurons as long as they may form synaptic contacts by serial ultrathin section observation.

With regard to the functional significance of DGKlike immunoreactivity in the immunostained neurons, as stated in Introduction, there have been studies showing several molecules involved in the PI-signal including DGK in C. elegans which is a species of Nematoda, phylogenically the next higher phylum to the $O V$ (Merida et al.; Tsunozaki et al.). The present immunostaining pattern with the rat DGK $\zeta$ antibody in the $O V$ is quite different from that with the rat DGK $\gamma$ antibody in the same parasite as previously reported by the present authors (Kondo \& Hipkaeo). It is thus likely that the immunostainings in the present and previous studies by us are due to individually discrete DGKs or DGK-like molecules of the $O V$. It is necessary to first confirm the sizes of the individual immunoreactive bands in immunoblotting analysis, and then to analyze the molecular sequences of the antigen in the $O V$ immunoreacted with the antibody for rat DGK $\zeta$. When these questions be clarified, it would be necessary to analyze how DGK $\zeta$ and its related signaling are involved in neuronal functions of the $O V$. Although rat $\mathrm{DGK} \zeta$ is known to occur often in the cell nucleus of various mammalian organs/tissues (Goto \& Kondo, 1996; Hozumi et al., 2003), the present immunolocalization was found to occur in mitochondria in the $O \mathrm{~V}$ cells. The immuno-localization in mitochondria, but not nucleus, is also worth further examining of its molecular sequence. 
HIPKAEO, W.; TECHATAWEEWAN, N.; SAKAEW, W.; MALEEWONG, W.; SRIPA, B.; CHOMPHOO, S.; HOZUMI, Y.; GOTO, K. \& KONDO, H. Identification in immuno-electron microscopy of solitary multi-polar peripheral neurons of adult Opisthorchis viverrini by antibody against rat diacylglycerol kinase. Int. J. Morphol., 34(2):471-477, 2016.

\section{ACKNOWLEDGEMENTS}

This work was supported by the research grants from Faculty of Medicine, Khon Kaen University (No. I57323 and RG57301). It was partially supported by TRF Senior Research Scholar Grant, Thailand Research Fund grant $\mathrm{N}^{\circ}$ RTA5880001. The authors would like to thank Polsan Y and Hipkaeo D for their technical supports.

HIPKAEO, W.; TECHATAWEEWAN, N.; SAKAEW, W.; MALEEWONG, W.; SRIPA, B.; CHOMPHOO, S.; HOZUMI, Y.; GOTO, K. \& KONDO, H. Identificación por microscopía imunoelectrónica de las neuronas periféricas multipolares solitarias del Opisthorchis viverrini adulto mediante anticuerpo contra la diacilglicerol kinasa de ratas. Int. J. Morphol., 34(2):471-477, 2016.

RESUMEN: Mediante el uso del anticuerpos DGK para rata se determinó un número considerable de células inmunopositivas en el Opisthorchis viverrini $(\mathrm{OV})$. Las células inmunopositivas aparecían solitarias y se distribuían simétricamente al eje longitudinal de la $O V$. Algunas estaban ubicadas en las proximidades de los órganos internos como el útero, ovarios, testículos, glándulas vitelinas e intestino. Las células inmunoteñidas extendían sus procesos horizontalmente u oblicuamente al eje longitudinal de la $O V$. Por microscopía inmunoelectrónica, las células inmunopositivas se caracterizaron por presentar mitocondrias intensamente teñidas, citoplasma con tinción débil e inmunonegatividad en núcleos pobres en cromatina. También se observó en las células, vacuolas de diversos tamaños sin inmunorreactividad. Se encontraron procesos celulares sin inmunorreactividad para cerrar finamente todas las superficies de las células y procesos, y se continuaron con los procesos de partición intersticiales que contenían núcleos y agregación de microfibrillas a cierta distancia de las envolturas citoplásmicas. El presente hallazgo sugiere la posibilidad de que las células inmunoteñidas son neuronas periféricas envueltas por glia periférica y que la glía presenta origen mesenquimal debido a su continuidad citoplasmática con los procesos de partición intersticiales. La naturaleza motora o sensorial de las neuronas aún no se ha dilucidado.

PALABRAS CLAVE: DGK; Inmunoreactividad; Neuronas periféricas; Glia; Opisthorchis viverrini; Ultraestructura.

\section{REFERENCES}

Barton, C. L.; Halton, D. W.; Shaw, C.; Maule, A. G. \& Johnston, C. F. An immunocytochemical study of putative neurotransmitters in the metacercariae of two strigeoid trematodes from rainbow trout (Oncorhynchus mykiss). Parasitol. Res., 79(5):389-96, 1993.

Biserova, N. M. Do glial cells exist in the nervous system of parasitic and free-living flatworms? An ultrastructural and immunocytochemical investigation. Acta. Biol. Hung., 59 (Suppl.):209-19, 2008.

Bullock, T. H. \& Horridge, G. A. Structure and Function in the Nervous Systems of Invertebrates. San Francisco, W. H. Freeman, 1965.

Fawcett, D. W.; Bloom, W. \& Raviola, E. A Textbook of Histology. $12^{\text {th }}$ ed. New York, Chapman \& Hall, 1994.

Goto, K. \& Kondo, H. A 104-kDa diacylglycerol kinase containing ankyrin-like repeats localizes in the cell nucleus. Proc. Natl. Acad. Sci. U. S. A., 93(20):11196-201, 1996.

Goto, K.; Hozumi, Y.; Nakano, T.; Saino-Saito, S. \& Martelli, A. M. Lipid messenger, diacylglycerol, and its regulator, diacylglycerol kinase, in cells, organs, and animals: history and perspective. Tohoku J. Exp. Med., 214(3):199-212, 2008.

Gustafsson, M. K.; Terenina, N. B.; Kreshchenko, N. D.; Reuter, M.; Maule, A. G. \& Halton, D. W. Comparative study of the spatial relationship between nicotinamide adenine dinucleotide phosphate-diaphorase activity, serotonin immunoreactivity, and GYIRFamide immunoreactivity and the musculature of the adult liver fluke, Fasciola hepatica (Digenea, fasciolidae). J. Comp. Neurol., 429(1):71-9, 2001.

Gustafsson, M. K.; Halton, D. W.; Kreshchenko, N. D.; Movsessian, S. O.; Raikova, O. I.; Reuter, M. \& Terenina, N. B. Neuropeptides in flatworms. Peptides, 23(11):2053-61, 2002.

Hozumi, Y.; Ito, T.; Nakano, T.; Nakagawa, T.; Aoyagi, M.; Kondo, H. \& Goto, K. Nuclear localization of diacylglycerol kinase zeta in neurons. Eur. J. Neurosci., 18(6):1448-57, 2003.

Kanoh, H.; Yamada, K. \& Sakane, F. Diacylglycerol kinases: emerging downstream regulators in cell signaling systems. J. Biochem., 131(5):629-33, 2002.

Kondo, H. Immunohistochemical analysis of the localization of neuropeptides in the adrenal gland. Arch. Histol. Jpn., 48(5):453-81, 1985.

Kondo, H. \& Hipkaeo, W. Advantages of embedment-free section transmission electron microscopy. Microsc. Res. Tech., 76(12):1257-65, 2013.

Leksomboon, R.; Chaijaroonkhanarak, W.; Arunyanart, C.; Umka, J.; Jones, M. K. \& Sripa, B. Organization of the nervous system in Opisthorchis viverrini investigated by histochemical and immunohistochemical study. Parasitol. Int., 61(1):107$11,2012 b$.

Leksomboon, R.; Jones, M. K.; Chaijaroonkhanarak, W. \& Chaiwong, T.; Khrongyut, S. \& Sripa, B. The ultrastructure of the brain of adult liver fluke, Opisthorchis viverrini. Int. J. Parasitol. Res., 4(2):90-3, 2012a. 
HIPKAEO, W.; TECHATAWEEWAN, N.; SAKAEW, W.; MALEEWONG, W.; SRIPA, B.; CHOMPHOO, S.; HOZUMI, Y.; GOTO, K. \& KONDO, H. Identification in immuno-electron microscopy of solitary multi-polar peripheral neurons of adult Opisthorchis viverrini by antibody against rat diacylglycerol kinase. Int. J. Morphol., 34(2):471-477, 2016.

Mérida, I.; Avila-Flores, A. \& Merino, E. Diacylglycerol kinases: at the hub of cell signalling. Biochem. J., 409(1):1-18, 2008.

Morris, J.; Cardona, A.; De Miguel-Bonet, Mdel. M. \& Hartenstein, V. Neurobiology of the basal platyhelminth Macrostomum lignano: map and digital 3D model of the juvenile brain neuropile. Dev. Genes. Evol., 217(8):569-84, 2007.

Oikonomou, G. \& Shaham, S. The glia of Caenorhabditis elegans. Glia, 59(9):1253-63, 2011.

Putney, J. W. Jr.; McKinney, J. S.; Aub, D. L. \& Leslie, B. A. Phorbol ester-induced protein secretion in rat parotid gland. Relationship to the role of inositol lipid breakdown and protein kinase $\mathrm{C}$ activation in stimulus-secretion coupling. Mol. Pharmacol., 26:261-6, 1984.

Radojcic, T. \& Pentreath, V. W. Invertebrate glia. Prog. Neurobiol., 12(2):115-79, 1979.

Shin, H. R.; Oh, J. K.; Masuyer, E.; Curado, M. P.; Bouvard, V.; Fang, Y. Y.; Wiangnon, S.; Sripa, B. \& Hong, S. T. Epidemiology of cholangiocarcinoma: an update focusing on risk factors. Cancer Sci., 101(3):579-85, 2010.

Sriamporn, S.; Pisani, P.; Pipitgool, V.; Suwanrungruang, K.; Kamsa-ard, S. \& Parkin, D. M. Prevalence of Opisthorchis viverrini infection and incidence of cholangiocarcinoma in Khon Kaen, Northeast Thailand. Trop. Med. Int. Health, 9(5):588-94, 2004.

Stirling, J. W. Immuno- and affinity probes for electron microscopy: a review of labeling and preparation techniques. J. Histochem. Cytochem., 38(2):145-57, 1990.

Sukhdeo, S. C. \& Sukhdeo, M. V. Ontogenetic development of the brain of the platyhelminth Fasciola hepatica. Tissue Cell, 22(1):39-50, 1990.

Terenina, N. B.; Poddubnaya, L. G.; Tolstenkov, O. O. \& Gustafsson, M. K. An immunocytochemical, histochemical and ultrastructural study of the nervous system of the tapeworm Cyathocephalus truncatus (Cestoda, Spathebothriidea). Parasitol. Res., 104(2):267-75, 2009.

Tsunozaki, M.; Chalasani, S. H. \& Bargmann, C. I. A behavioral switch: cGMP and PKC signaling in olfactory neurons reverses odor preference in C. elegans. Neuron, 59(6):959-71, 2008.
Correspondence to:

Wiphawi Hipkaeo

Electron Microscopy Unit

Department of Anatomy

Faculty of Medicine

Khon Kaen University

THAILAND

Email: wiphawi @kku.ac.th

Received: 29-11-2015

Accepted: 25-02-2016 